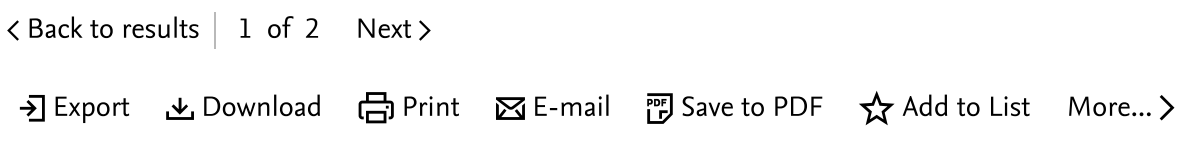

International Journal of Mobile Computing and Multimedia Communications • Volume 10, Issue 2 , Pages $19-41 \cdot 2019$

Document type

Article

Source type

Journal

ISSN

19379412

DOI

10.4018/IJMCMC.2019040102

Publisher

IGI Global

Original language

English

View less $\wedge$

\section{Human linguistic perception of distances for location-aware systems}

Olowolayemo A. ${ }^{a}, \quad$ Mantoro T. ${ }^{b}$

国 Save all to author list

a Universiti Malaysia Sarawak, Kota Samarahan, Malaysia

b Sampoerna University, Jakarta, Indonesia

$\mid$\begin{tabular}{l|l}
21 & View all metrics > \\
Views count $?$ &
\end{tabular}

Full text options $\checkmark$

Abstract

Author keywords

Indexed keywords

SciVal Topics

Metrics

\section{Abstract}

Location referencing relative to landmarks or between two points of interest is often presented by navigation systems (e.g., GPS, Google Maps) in quantitative terms (e.g., 10om, 2km, etc.). However, humans refer to distances between points of interests in linguistic forms, such as very close, far, almost there, nearby, etc. When location information is presented to humans in quantitative terms, they often reprocess the quantities into linguistic terms and articulate it in linguistic labels because quantitative
Cited by 0 documents

Inform me when this document is cited in Scopus:

Set citation alert >

\section{Related documents}

Linguistic location authority: An intricate imperative

Olowolayemo, A. , Tap, A.O.M. , Mantoro, T.

(2015) Critical Socio-Technical Issues Surrounding Mobile Computing

Computing with words and its relationships with fuzzistics

Mendel, J.M.

(2007) Information Sciences

Computing with words: Zadeh, turing, popper and occam

Mendel, J.M.

(2007) IEEE Computational Intelligence Magazine

View all related documents based on references

Find more related documents in Scopus based on:

Authors > Keywords > 
articulations are not directly in line with the natural human cognition. Therefore, this research seeks to evaluate the possibility of applying perceptive computing to reprocess quantitative location references from landmarks or two points of interest into linguistic labels easily understood by humans. A comparative analysis between the perception of quantitative distances and similar physical distances in an environment familiar to the subjects has been carried out, and there is a clear disparity between the perceptions in these two contexts. Copyright (C) 2019, IGI Global. Copying or distributing in print or electronic forms without written permission of IGI Global is prohibited.

\section{Author keywords}

Assistive Technology; Blind Navigation; Human-Computer Interaction; Indoor Location Authority; Indoor Navigation; Indoor Positioning; Location-Based Services

Indexed keywords

SciVal Topics

Metrics

References (56)

View in search results format >

All

Export 合Print 四E-mail 帤 Save to PDF Create bibliography

1 Alter, A.L., Balcetis, E.

Fondness makes the distance grow shorter: Desired locations seem closer because they seem more vivid

(2011) Journal of Experimental Social Psychology, 47 (1), pp. 16-21. Cited 48 times.

doi: 10.1016/j.jesp.2010.07.018

View at Publisher

2 Barrett, L.F., Mesquita, B., Gendron, M.

Context in emotion perception

(2011) Current Directions in Psychological Science, 20 (5), pp. 286-290. Cited 397 times.

doi: $10.1177 / 0963721411422522$

View at Publisher

3 Bhowmick, A., Hazarika, S.M.

An insight into assistive technology for the visually impaired and blind people: state-of-the-art and future trends

(2017) Journal on Multimodal User Interfaces, 11 (2), pp. 149-172. Cited 91

times.

http://www.springer.com.ezaccess.library.uitm.edu.my/computer/user+interfa ces/journal/12193

doi: $10.1007 / \mathrm{s} 12193-016-0235-6$

View at Publisher 
4 Pérez, I.J., Cabrerizo, F.J., Morente-Molinera, J.A., Ureña, R., Herrera-Viedma, E.

Reaching consensus in digital libraries: A linguistic approach (Open Access)

(2014) Procedia Computer Science, 31, pp. 449-458. Cited 9 times. http://www.sciencedirect.com.ezaccess.library.uitm.edu.my/science/journal/18 $\underline{770509}$

doi: 10.1016/j.procs.2014.05.289

View at Publisher

5 Chameau, J.-L., Santamarina, J.C.

Membership functions I: Comparing methods of measurement (Open Access)

(1987) International Journal of Approximate Reasoning, 1 (3), pp. 287-

301. Cited 85 times.

doi: $10.1016 / 50888-613 \times(87) 80003-8$

View at Publisher

6 Civanlar, M.R., Trussell, H.J.

Constructing membership functions using statistical data

(1986) Fuzzy Sets and Systems, 18 (1), pp. 1-13. Cited 261 times.

doi: 10.1016/0165-0114(86)90024-2

View at Publisher

7 Clementini, E., Di Felice, P., Hernández, D.

Qualitative representation of positional information

(Open Access)

(1997) Artificial Intelligence, 95 (2), pp. 317-356. Cited 211 times. doi: 10.1016/S0004-3702(97)00046-5

View at Publisher

8 Cornelissen, A.M.G.

(2003) The Two Faces of Sustainability: Fuzzy Evaluation of Sustainable Development. Cited 32 times.

Wageningen University

10 Dillon, A., Richardson, J., McKnight, C. Navigation in hypertext: A critical review of the concept (1990) Human-Computer Interaction-INTERACT'90, pp. 587-592. Cited 61 times.

Amsterdam: North Holland 
11 Dillon, A., Richardson, J., McKnight, C.

Institutionalising human factors in the design process: The ADONIS

experience

(1991) Contemporary Ergonomics'91, pp. 421-426. Cited 2 times.

London: Taylor and Francis

12 Dong, Y., Zha, Q., Zhang, H., Kou, G., Fujita, H., Chiclana, F., Herrera-

Viedma, E.

Consensus reaching in social network group decision making:

Research paradigms and challenges (Open Access)

(2018) Knowledge-Based Systems, 162, pp. 3-13. Cited 242 times.

https://www-journals-elsevier-com.ezaccess.library.uitm.edu.my/knowledgebased-systems

doi: 10.1016/j.knosys.2018.06.036

View at Publisher

13 Dubois, D., Prade, $\mathrm{H}$.

Fuzzy sets and statistical data

(1986) European Journal of Operational Research, 25 (3), pp. 345-356. Cited 139 times.

doi: 10.1016/0377-2217(86)90266-3

View at Publisher

14 Elmannai, W., Elleithy, K.

Sensor-based assistive devices for visually-impaired people:

Current status, challenges, and future directions (Open Access)

(2017) Sensors (Switzerland), 17 (3), art. no. 565. Cited 122 times.

http://www.mdpi.com/1424-8220/17/3/565/pdf

doi: $10.3390 /$ s 17030565

View at Publisher

15 Gallagher, T., Wise, E., Yam, H.C., Li, B., Ramsey-Stewart, E., Dempster, A.G., Rizos, C.

Indoor navigation for people who are blind or vision impaired: Where are we and where are we going?

(2014) Journal of Location Based Services, 8 (1), pp. 54-73. Cited 23 times. doi: 10.1080/17489725.2014.895062

View at Publisher

16 Gottsegen, J., Montello, D., Goodchild, M.F.

A comprehensive model of uncertainty in spatial data

(1999) Spatial Accuracy Assessment: Land Information Uncertainty in Natural Resources, pp. 175-181. Cited 15 times.

Academic Press 
17 Hernández, D., Clementini, E., Di Felice, P.

Qualitative distances

(1995) Lecture Notes in Computer Science (including subseries Lecture Notes in Artificial Intelligence and Lecture Notes in Bioinformatics), 988, pp. 45-

57. Cited 115 times.

http://springerlink.com.ezaccess.library.uitm.edu.my/content/0302-

9743/copyright/2005/

ISBN: 3540603921; 978-354060392-4

doi: $10.1007 / 3-540-60392-1 \_4$

View at Publisher

18 Hoffman, D.L.

(1994) Note on the Ventana Coefficient of Consensus. Cited 2 times.

Department of Computer Science, Australian Defence Force Academy,

University College, University of New South Wales, (Technical report

(Australian Defence Force Academy. Dept. of Computer Science))

http://books.google.com.my/books?id=92SENAAACAAJ.

19 Hsiao, W.-F., Lin, H.-H., Chang, T.-M.

Value-based consensus measure on verbal opinions

(2005) Proceedings of the Annual Hawaii International Conference on System Sciences, p. 9.

20 Hsiao, W.-F., Lin, H.-H., Chang, T.-M.

Fuzzy consensus measure on verbal opinions

(2008) Expert Systems with Applications, 35 (3), pp. 836-842. Cited 12 times. doi: 10.1016/j.eswa.2007.07.040

View at Publisher

21 Jong, J.H.

(1994) Qualitative Reasoning about Distances and Directions in Geographic Space. Cited 10 times.

University of Maine

22 Kim, J.-E., Bessho, M., Kobayashi, S., Koshizuka, N., Sakamura, K.

Navigating visually impaired travelers in a large train station using smartphone and Bluetooth Low Energy

(2016) Proceedings of the ACM Symposium on Applied Computing, 04-08April-2016, pp. 604-611. Cited 51 times.

ISBN: 978-145033739-7

doi: $10.1145 / 2851613.2851716$

View at Publisher 
23 Kiuru, T., Metso, M., Utriainen, M., Metsävainio, K., Jauhonen, H.-M., Rajala, R., Savenius, R., (...), Sylberg, J.

Assistive device for orientation and mobility of the visually impaired based on millimeter wave radar technology-

Clinical investigation results (Open Access)

(2018) Cogent Engineering, 5 (1), art. no. 1450322. Cited 15 times.

http://www-tandfonline-com.ezaccess.library.uitm.edu.my/toc/oaen20/current doi: $10.1080 / 23311916.2018 .1450322$

View at Publisher

24 Klir, G.J., Yuan, B.

(1995) Fuzzy Sets and Fuzzy Logic: Theory and Applications. Cited 7625 times. Upper Saddle River, NJ: Prentice Hall

25 Lawry, J.

An alternative approach to computing with words

(2001) International Journal of Uncertainty, Fuzziness and Knowlege-Based Systems, 9 (SUPPL.), pp. 3-16. Cited 55 times.

doi: $10.1142 / \mathrm{S} 0218488501000958$

View at Publisher

26 Li, C.-C., Dong, Y., Herrera, F., Herrera-Viedma, E., Martínez, L.

Personalized individual semantics in computing with words for supporting linguistic group decision making. An application on consensus reaching (Open Access)

(2017) Information Fusion, 33, pp. 29-40. Cited 240 times.

http://www.elsevier.com.ezaccess.library.uitm.edu.my/inca/publications/store/ 6/2/0/8/6/2/index.htt

doi: 10.1016/j.inffus.2016.04.005

View at Publisher

27 Lindblad, J.

Topics of today Fuzzy Sets and Fuzzy Techniques: A note on the estimation of perimeter

(2007) Binary Case Fuzzy Case, 8.

28 Linstone, H.A., Turoff, M.

(2002) The Delphi Method. Cited 4864 times.

http://is.njit.edu/pubs/delphibook/delphibook.pdf

29 Liu, F., Mendel, J.M.

Encoding words into interval type-2 fuzzy sets using an interval approach

(2008) IEEE Transactions on Fuzzy Systems, 16 (6), pp. 1503-1521. Cited 261 times.

doi: 10.1109/TFUZZ.2008.2005002

View at Publisher 
(2006) Distributed Support for Intelligent Environments. Cited 4 times.

The Australian National University

31 Mantoro, T., Olowolayemo, A., Olatunji, S.O.

Mobile user location determination using extreme learning machine

(2010) Proceeding of the 3rd International Conference on Information and Communication Technology for the Moslem World: ICT Connecting Cultures, ICT4M 2010, art. no. 5971898, pp. D25-D30. Cited 7 times. ISBN: 978-979194891-3

doi: $10.1109 /$ ICT4M.2010.5971898

View at Publisher

32 Mantoro, T., Olowolayemo, A., Olatunji, S.O., Ayu, M.A., Tap, A.O.M.

Extreme learning machine for user location prediction in mobile environment (Open Access)

(2011) International Journal of Pervasive Computing and Communications, 7 (2), pp. 162-180. Cited 18 times. doi: $10.1108 / 17427371111146446$

View at Publisher

33 McKnight, C., Dillon, A., Richardson, J.

A comparison of linear and hypertext formats in information retrieval (1990) HYPERTEXT: State of the Art, pp. 10-19. Cited 63 times.

R. McAleese \& C. Green (Eds), Oxford, UK: Intellect

34 Mendel, J.M.

Computing with words, when words can mean different things to different people

(1999) Proc. 3rd Int. ICSC Symp. Fuzzy Logic Appl., pp. 158-164. Cited 102

times.

$\square 35$ Mendel, J.M., Zadeh, L.A., Trillas, E., Yager, R., Lawry, J., Hagras, H., Guadarrama, S.

What computing with words means to me: Discussion forum

(2010) IEEE Computational Intelligence Magazine, 5 (1), art. no. 5386101, pp. 20-26. Cited 164 times.

doi: $10.1109 / \mathrm{MCl} .2009 .934561$

View at Publisher 
36 Mendel, J.M., Wu, D.

Perceptual Computing: Aiding People in Making Subjective Judgments

(2010) Perceptual Computing: Aiding People in Making Subjective Judgments. Cited 431 times.

http://onlinelibrary.wiley.com.ezaccess.library.uitm.edu.my/book/10.1002/978 0470599655

ISBN: 978-047047876-9

doi: $10.1002 / 9780470599655$

View at Publisher

37 Norwich, A.M., Turksen, I.

The construction of membership functions

(1982) Fuzzy Sets and Possibility Theory. Cited 43 times.

Pergamon

38 Norwich, A.M., Turksen, I.B.

A model for the measurement of membership and the consequences of its empirical implementation

(1984) Fuzzy Sets and Systems, 12 (1), pp. 1-25. Cited 143 times. doi: 10.1016/0165-0114(84)90047-2

View at Publisher

39 Olowolayemo, A., Tap, A.O.M., Mantoro, T. Linguistic location authority: An intricate imperative (2016) Geospatial Research: Concepts, Methodologies, Tools, and Applications, pp. 32-47.

IGI Global

40 Renner, R.S., Velichkovsky, B.M., Helmert, J.R.

The perception of egocentric distances in virtual environments - A review (Open Access)

(2013) ACM Computing Surveys, 46 (2), art. no. 23. Cited 246 times. doi: $10.1145 / 2543581.2543590$

View at Publisher

41 Shafer, S.A.N.

Location authorities for ubiquitous computing (2003) Workshop on Location-Aware Computing, Ubicomp', pp. 13-15. Cited 6 times.

42 Suganya, R. (2017) An Audio Based Application to Aid Visually Impaired Users Academic Press 
43 Tapia García, J.M., Del Moral, M.J., Martínez, M.A., Herrera-Viedma, E.

A consensus model for group decision making problems with linguistic interval fuzzy preference relations

(2012) Expert Systems with Applications, 39 (11), pp. 10022-10030. Cited 138 times.

doi: 10.1016/j.eswa.2012.02.008

View at Publisher

44 Tolman, E.C.

Cognitive maps in rats and men

(1948) Psychological Review, 55 (4), pp. 189-208. Cited 3314 times.

doi: $10.1037 / \mathrm{h} 0061626$

View at Publisher

45 Turksen, I.B.

Measurement of membership functions

(1986) Applications of Fuzzy Set Theory in Human Factors. Cited 30 times.

Amsterdam: Elsevier Science Publishers

46 Turksen, I.B.

Stochastic fuzzy sets: A survey

(1988) Lecture Notes in Economics and Mathematical Systems. Combining

Fuzzy Imprecision with Probabilistic Uncertainty in Decision Making SE -

13, pp. 168-183. Cited 18 times.

J. Kacprzyk \& M. Fedrizzi (Eds), Springer

47 Turksen, I.B.

Measurement of membership functions and their acquisition

(1991) Fuzzy Sets and Systems, 40 (1), pp. 5-38. Cited 190 times.

doi: 10.1016/0165-0114(91)90045-R

View at Publisher

48 Burhan Turksen, I., Willson, I.A.

A fuzzy set preference model for consumer choice

(1994) Fuzzy Sets and Systems, 68 (3), pp. 253-266. Cited 44 times.

doi: 10.1016/0165-0114(94)90182-1

View at Publisher

49 Wallsten, T.S., Budescu, D.V.

Comment (Open Access)

(1990) Statistical Science, 5 (1), pp. 23-26. Cited 13 times.

doi: $10.1214 / \mathrm{ss} / 1177012248$

View at Publisher 
50 Wu, D., Mendel, J.M., Coupland, S.

(2012) Enhanced Interval Approach for Encoding Words into Interval Type-2 Fuzzy Sets and Its Convergence Analysis

Academic Press

51 Yu, X., Ganz, A.

Audible vision for the blind and visually impaired in indoor open spaces

(2012) Proceedings of the Annual International Conference of the IEEE Engineering in Medicine and Biology Society, EMBS, art. no. 6347143, pp. 5110-5113. Cited 3 times.

ISBN: 978-142444119-8

doi: 10.1109/EMBC.2012.6347143

View at Publisher

52 Zadeh, L.A.

Fuzzy sets (Open Access)

(1965) Information and Control, 8 (3), pp. 338-353. Cited 55874 times. doi: 10.1016/S0019-9958(65)90241-X

View at Publisher

53 Zadeh, L.A.

Computing with Words and perceptions - A paradigm shift (2009) Information Reuse \& Integration, 2009. IRI'09. IEEE International Conference on, p. viii-x. Cited 27 times.

54 Zadeh, L.A.

What is computing with words (Cww)? Computing with words (2013) Studies in Fuzziness and Soft Computing. Cited 4 times. Berlin: Springer Berlin Heidelberg

55 Zadra, J.R., Clore, G.L.

Emotion and perception: The role of affective information (Open Access)

(2011) Wiley Interdisciplinary Reviews: Cognitive Science, 2 (6), pp. 676685. Cited 122 times. doi: $10.1002 /$ wcs.147

View at Publisher

56 Zwick, R.

A note on random sets and the thurstonian scaling methods

(1987) Fuzzy Sets and Systems, 21 (3), pp. 351-356. Cited 14 times. doi: 10.1016/0165-0114(87)90134-5

View at Publisher

Mantoro, T.; Sampoerna University, Jakarta, Indonesia

(C) Copyright 2019 Elsevier B.V., All rights reserved. 


$\begin{array}{lll}\text { About Scopus } & \text { Language } & \text { Customer Service } \\ \text { What is Scopus } & \text { 日本語に切り替える } & \text { Help } \\ \text { Content coverage } & \text { 切换到简体中文 } & \text { Contact us } \\ \text { Scopus blog } & \text { 切換到繁體中文 } & \\ \text { Scopus API } & \text { Русский язык } & \\ \text { Privacy matters } & & \end{array}$

ELSEVIER

Terms and conditions $\pi \quad$ Privacy policy $\pi$

Copyright (C) Elsevier B.V ז. All rights reserved. Scopus ${ }^{\circledR}$ is a registered trademark of Elsevier B.V.

We use cookies to help provide and enhance our service and tailor content. By continuing, you agree to the

Q RELX use of cookies. 